S. Afr. J. Agric. Ext.

Vol. 45, No. 2, 2017: $38-48$

Matiwane \&

DOI: http://dx.doi.org/10.17159/2413-3221/2017/v45n2a432

Terblanché

(Copyright)

\title{
A COMPARISON OF PROJECT PARTICIPANTS AND EXTENSION OFFICERS' PERCEPTIONS OF THE MARKET IN AGRICULTURAL PROJECTS IN THE NORTH WEST PROVINCE, SOUTH AFRICA
}

\author{
Matiwane, M. B. ${ }^{9} \&$ Terblanché, S. E. ${ }^{10}$
}

\begin{abstract}
The study examined the perception of project participants and extension officers regarding marketing of agricultural produce in agricultural projects in the North West Province. The objective of the study was primarily to compare the perceptions of project participants and extension officers. When establishing a project, market and its stability with regards to the produce of the project has to be established on whether the project will maximise profit, maintain market share, or consolidate market position. The major findings of the study according to both project participants and extension officer respondents revealed that: (a)The market was reasonable according to $54 \%$ of project participants and $53 \%$ of extension officer respondents; (b) The market remained unchanged according to $48 \%$ of both respondent categories; (c) Produce slightly met the market requirements in terms of quality; (d) Produce did not meet market requirements in terms of contract; (e) The market price was average; (f) The market assessment in terms of the quantity it can absorb was average; (g) Project participants used hired transport according to $35 \%$ of both respondent categories; and (h) $33 \%$ of both respondent categories indicated that produce were marketed locally within the community.
\end{abstract}

Keywords: Perception, Projects, Market, Produce, Project participants, Extension officers

\section{INTRODUCTION}

Agricultural marketing covers the services involved in moving an agricultural product from the farm to the consumer. Numerous interconnected activities are involved in doing this, such as planning production, growing and harvesting, grading, packing, transport, storage, agroand food-processing, distribution, advertising, and sale. It is always essential to make an assessment of the market in terms of the quantity it can absorb, so that one knows what will happen if one increases the rate of production and how it will affect market share, through assessing competitors in the market (Burke, 2003). Whilst quality is essential in marketing of produce, quantity to be supplied periodically is vital in keeping the contract between the producer and buyer in harmony. Once a project is established, regular assessment of the market and supply and demand curve needs to be monitored so that the demand for the product now and forecast demand is known. Chipita, Christoplos \& Katz (2008) pointed out that the agricultural market environment is changing with unprecedented speed and in a very diverse way, globally and locally. These dynamics affect rural people even in the most isolated areas. Extension advisory services in the most isolated areas can play an important role of increasing access to market by assisting needy farmers.

\footnotetext{
${ }^{9}$ Senior Manager, Department of Agriculture and Rural Development, Private Bag X82070, Rustenburg, 0300. Tel.: 014592 8201. This article is part of the author's PhD thesis. University of Pretoria, South Africa. Email: mbmatiwane@nwpg.gov.za

${ }^{10}$ Senior Lecturer, Department of AEERD, Faculty of Natural \& Agricultural Science, University of Pretoria. Tel.: 012420 4623, Email: fanie.terblanche@ up.ac.za
} 
S. Afr. J. Agric. Ext.

Vol. 45, No. 2, 2017: $38-48$

DOI: http://dx.doi.org/10.17159/2413-3221/2017/v45n2a432
Matiwane \&

Terblanché

(Copyright)

Financial awareness of farmers is always essential to make sure that they make a proper assessment of all resources that they manage. Furthermore, they must be aware of financial loss (Lombard, Hadebe, Louw \& Botha, 1995). They must also be able to budget independently and be willing to interpret financial records so that they can make informed decisions.

According to Alonge (2002), many rural agricultural communities in the less developed countries (LDCs) are isolated and enjoy little if any access to formal government institutions and social amenities. When establishing a project, market research is normally conducted in order to check its stability with regards to the produce of the project. In a study conducted by Kirsten and Machete in the North West Province (2005), citing FAO (2001: 19-21), the following findings were indicated: (a) $10 \%$ of the projects were essentially residential and no agricultural production was taking place, and (b) $49 \%$ of the projects recorded production and marketing of a commodity, while $29 \%$ of projects revealed to have had no production occur since land had been transferred. The effect of location on the project must therefore be considered and the logistic requirements during the project and subsequent operation be met through existing roads and ports (Burke, 2003)

Market seems to be an ingredient that explains the difference between the many failed projects and few successful ones. Farmers frequently consider marketing as being their major problem. However, while they are able to identify such problems as poor prices, lack of transport and high post-harvest losses, they are often poorly equipped to identify potential solutions. Successful marketing requires learning new skills, new techniques and new ways of obtaining information.

This study focuses on the perception of project participants and extension officers concerning marketing of agricultural produce. The study compares the perceptions of the two categories of respondents in relation to all variables identified for this study.

\section{OBJECTIVE OF THE STUDY}

In general, the objective of the study was to compare the perceptions of project participants with that of extension officers regarding the market.

The specific objectives of the study intended to:

- Assess the market in terms of: (i) performance status; (ii) availability; (iii) transport costs; and (iv) market place as perceived by project participants and extension officers.

- Determine the degree to which the produce meets market requirement in terms of: (i) quality; (ii) quantity it can absorb; (iii) contract; and (iv) price as perceived by project participants and extension officers.

\section{THE RESEARCH METHODOLOGY}

\subsection{Orientation and planning}

Provincial statistical figures were extracted from Provincial and Districts reports. A list of projects, their addresses and location were obtained from Local Agricultural Development Centres (LADC). Reconnaissance survey was done in all districts to 
S. Afr. J. Agric. Ext.

Vol. 45, No. 2, 2017: $38-48$

DOI: http://dx.doi.org/10.17159/2413-3221/2017/v45n2a432

check the status of projects before the actual commencement of an in-depth survey.

Furthermore, field staff were consulted on various aspects of the survey.

\subsection{Information source}

Information on project location, size, number of participants and gender was obtained from LADC, District Office and Head Office (Mmabatho). Information on the potential of the areas, soil types, livestock types, etc. was obtained from the Scientific Technical Support Services (STSS) in Potchefstroom.

\subsection{Questionnaire design}

The questionnaire was designed according to the problem conceptualisation framework method as designed by Düvel (1995). A combination of structured (closed questions) and unstructured (open-ended questions) were used.

\subsection{Sample size}

Stratified random sampling was used. The survey was conducted on $25 \%$ of the total number of projects submitted by the districts. The $25 \%$ covered diverse projects established from different locations, groups and individuals, communal setup and private land, as well as dormant and fully fledged functional projects.

\subsection{Interview procedure}

In an effort to limit the "I don't know", "I'm not sure", and "That's too private", the importance of the respondent's information was emphasised during the discussions. The flow of discussion was structured in such a way that the interview becomes interesting. Personal or sensitive questions regarding income for example were asked towards the end of the interview.

\subsection{Data analysis}

Data were entered into the computer software programme, Statistical Package for the Social Sciences (SPSS, version 19.0) and frequencies were run for each survey item by the Department of Statistics of the University of Pretoria. The following statistical tests were conducted:

(i) Pearson Chi-Square test

(ii) t-test for Equality of Means

\section{FINDINGS}

\subsection{Market availability as perceived by project participants and extension officers}


S. Afr. J. Agric. Ext.

Vol. 45, No. 2, 2017: $38-48$

DOI: http://dx.doi.org/10.17159/2413-3221/2017/v45n2a432
Matiwane \&

Terblanché

(Copyright)

Consideration must be made by project participants/farmers on maintaining market share or consolidating market positions and utilisation of the work force when selecting a project (Burke, 2003:2-4, 48-59). With any project that earmarks funding from the Department of Agriculture and Rural Development in the Province a market has to be established /identified before approval of such funds. The perception of the two respondent categories on market availability was assessed using a 4-point Likert scale with response options for no market, a reasonable market, a good market, and a very good market. The results of the Chi-Square test $\left(x^{2}=4.512 ; \mathrm{p}=0.213\right)$ indicates that there is no statistically significant association between the two types of respondent categories at the 5\% significant level with regards to market availability. According to project participants (54\%) and extension officers (53\%), markets are reasonable while $20 \%$ of project participants and $10 \%$ of extension officers indicated that there is no market. Although a reasonably higher percentage indicated a reasonable market, efforts should be made by extension officers to assist farmers to access a good market for their produce.

\subsection{Market status as perceived by project participants and extension officers}

When establishing a project, market research normally needs to be conducted in order to check its stability with regards to the produce of the project. In this instance, the market was assessed in terms of its performance during the duration of the project. Assessment of the perception of the two respondent categories was based on whether the market has improved, decreased or remained unchanged. According to Table 1, the majority (48\%) of both respondent categories indicated that the market remained unchanged, while $19 \%$ of project participants and $9 \%$ of extension officers indicated that the market decreased. A total of $37 \%$ of both respondent categories indicated market improvement which is a positive sign that needs to be maintained and further improved upon. The Pearson Chi-Square test indicated that there is no statically significant difference $\left(x^{2}=3.798 ; \mathrm{p}=0.151\right)$ at the $5 \%$ significant level between the two respondent categories with regards to the market status.

Table 1: Market status as perceived by project participants and extension officers.

\begin{tabular}{|lc|l|l|l|}
\hline \multirow{2}{*}{ Market status categories } & & \multicolumn{2}{|l|}{ Respondent categories } & \multirow{2}{*}{ Total } \\
\cline { 3 - 5 } & & $\begin{array}{l}\text { Project } \\
\text { participants }\end{array}$ & $\begin{array}{l}\text { Extension } \\
\text { officers }\end{array}$ & \\
\hline 1. Market improved & $(\mathrm{n})$ & 41 & 32 & 73 \\
& $(\%)$ & $33.3 \%$ & $42.7 \%$ & $36.9 \%$ \\
\hline $\begin{array}{l}\text { 2. Market remained } \\
\text { unchanged }\end{array}$ & $(\mathrm{n})$ & 59 & 36 & 95 \\
\hline 3. Market decreased & $(\mathrm{n})$ & $48.0 \%$ & $48.0 \%$ & $48.0 \%$ \\
\hline Total & $(\%)$ & 23 & 7 & 30 \\
& $(\mathrm{~N})$ & 123 & $9.3 \%$ & $15.2 \%$ \\
\hline
\end{tabular}

$x^{2}=3.798 ; p=0.151$ 
S. Afr. J. Agric. Ext.

Vol. 45, No. 2, 2017: $38-48$

DOI: http://dx.doi.org/10.17159/2413-3221/2017/v45n2a432
Matiwane \&

Terblanché

(Copyright)

4.3 The degree to which the produce met market requirement in terms of quality according to project participants and extension officers

According to Regenesys School of Public Management (2002), planning for quality requirement for projects is essential to avoid project failure. As indicated in Table 2, the highest percentage of project participants (59\%) and extension officers $(53 \%)$ indicated that produce only slightly met the market quality requirements in terms of quality. The second largest percentage of both respondent categories (25\%) indicated that produce did not meet the market quality requirements. Only a very small percentage of both respondent categories $(3 \%)$ indicated that produce met the market quality requirements. The Chi-Square test results $\left(x^{2}=3.783 ; \mathrm{p}=0.611\right)$ indicates that there is no statistically significant difference for all type of respondents at the 5\% significant level with regards to the quality of the produce in terms of meeting market requirements at various projects in the province. If the quality of the produce does not meet the requirements set by the market, it could have disastrous effects on the success of the project. This finding indicates a serious problem that needs urgent attention because if the quality of the produce does not meet the market requirements, the farmers will lose the market.

Table 2: The degree to which the produce met the market requirements in terms of quality according to both respondent categories.

\begin{tabular}{|c|c|c|c|c|}
\hline \multirow{2}{*}{\multicolumn{2}{|c|}{ The degree of market quality requirement }} & \multicolumn{2}{|c|}{ Respondent categories } & \multirow{3}{*}{$\begin{array}{l}\text { Total } \\
50 \\
24.9 \% \\
\end{array}$} \\
\hline & & \multirow{2}{*}{\begin{tabular}{|l|}
$\begin{array}{l}\text { Project } \\
\text { participants }\end{array}$ \\
32 \\
$25.6 \%$ \\
\end{tabular}} & \multirow{2}{*}{\begin{tabular}{|l|}
$\begin{array}{l}\text { Extension } \\
\text { officers }\end{array}$ \\
18 \\
$23.7 \%$ \\
\end{tabular}} & \\
\hline $\begin{array}{l}\text { 1. Did not meet market quality } \\
\text { requirements at all. }\end{array}$ & $\begin{array}{l}(\mathrm{n}) \\
(\%)\end{array}$ & & & \\
\hline $\begin{array}{l}\text { 2. Did not meet market quality } \\
\text { requirements. }\end{array}$ & $\begin{array}{l}(\mathrm{n}) \\
(\%)\end{array}$ & $\begin{array}{l}11 \\
8.8 \% \\
\end{array}$ & $\begin{array}{l}12 \\
15.8 \% \\
\end{array}$ & $\begin{array}{l}23 \\
11.4 \% \\
\end{array}$ \\
\hline $\begin{array}{l}\text { 3. Market quality requirements } \\
\text { slightly met. }\end{array}$ & $\begin{array}{l}(\mathrm{n}) \\
(\%)\end{array}$ & $\begin{array}{l}74 \\
59.2 \%\end{array}$ & $\begin{array}{l}40 \\
52.6 \%\end{array}$ & $\begin{array}{l}114 \\
56.7 \%\end{array}$ \\
\hline $\begin{array}{l}\text { 4. Market quality requirements } \\
\text { met. }\end{array}$ & $\begin{array}{l}(\mathrm{n}) \\
(\%)\end{array}$ & $\begin{array}{l}3 \\
2.4 \% \\
\end{array}$ & $\begin{array}{l}2 \\
2.6 \% \\
\end{array}$ & $\begin{array}{l}5 \\
2.5 \% \\
\end{array}$ \\
\hline $\begin{array}{l}\text { 5. Market quality requirements } \\
\text { met to a large extent. }\end{array}$ & $\begin{array}{l}(\mathrm{n}) \\
(\%)\end{array}$ & $\begin{array}{l}3 \\
2.4 \% \\
\end{array}$ & $\begin{array}{l}1 \\
1.3 \% \\
\end{array}$ & $\begin{array}{l}4 \\
2.0 \% \\
\end{array}$ \\
\hline $\begin{array}{l}\text { 6. Market quality requirements } \\
\text { totally met. }\end{array}$ & $\begin{array}{l}(\mathrm{n}) \\
(\%)\end{array}$ & $\begin{array}{l}2 \\
1.6 \% \\
\end{array}$ & $\begin{array}{l}3 \\
3.9 \% \\
\end{array}$ & $\begin{array}{l}5 \\
2.5 \% \\
\end{array}$ \\
\hline Total & $\begin{array}{l}(\mathrm{N}) \\
(\%) \\
\end{array}$ & $\begin{array}{l}125 \\
100.0 \% \\
\end{array}$ & $\begin{array}{l}76 \\
100.0 \% \\
\end{array}$ & $\begin{array}{l}201 \\
100.0 \% \\
\end{array}$ \\
\hline
\end{tabular}

$x^{2}=3.783 ; \mathrm{p}=0.611$

\subsection{The degree to which the produce met market requirements in terms of contract according to project participants and extension officers}

Whilst quality is essential in marketing the produce, the quantity that has to be supplied periodically is essential to keep the contract between the producer and buyer in harmony. It is therefore essential that producers must always ask themselves the following two questions before entering into any contract with institutions or organisations as listed by Burke (2003): 
S. Afr. J. Agric. Ext.

Vol. 45, No. 2, 2017: $38-48$

DOI: http://dx.doi.org/10.17159/2413-3221/2017/v45n2a432
Matiwane \&

Terblanché

(Copyright)

(a) Will the project maximise profit? (b) Will the profit maintain market share, increase market share or consolidate market position? These questions will reassure the producer about his /her position in terms of entering into any agreement with any institution or organisation. According to Table 3, the highest percentage of project participants (59\%) and extension officers $(47 \%)$ indicated that produce did not meet the market requirements in terms of the contract. The second largest percentage of both respondent categories $(35 \%)$ indicated that the produce only slightly met the market contract requirements. Only a very small percentage of both respondent categories (3\%) indicated that produce met the market contract requirements also to a large extent and even totally. The Chi-Square test results $\left(x^{2}=\right.$ 5.465; $\mathrm{p}=0.353$ ) indicates that there is no statistically significant difference at the $5 \%$ significant level for both respondent categories. This finding once again clearly indicated a serious problem that needs to be attended to by extension officers.

Table 3: The degree to which the produce met the market requirements in terms of contract according to both respondent categories.

\begin{tabular}{|c|c|c|c|}
\hline \multirow[b]{2}{*}{$\begin{array}{l}\text { The degree of market contract } \\
\text { requirement }\end{array}$} & \multicolumn{2}{|c|}{ Type of respondent } & \multirow[b]{2}{*}{ Total } \\
\hline & \begin{tabular}{|l} 
Project \\
participants
\end{tabular} & $\begin{array}{l}\text { Extension } \\
\text { officers }\end{array}$ & \\
\hline $\begin{array}{l}\text { 1. Did not meet market contract }(\mathrm{n}) \\
\text { requirements at all. }\end{array}$ & $\begin{array}{l}69 \\
58.5 \% \\
\end{array}$ & $\begin{array}{l}32 \\
47.1 \% \\
\end{array}$ & $\begin{array}{l}101 \\
54.3 \% \\
\end{array}$ \\
\hline $\begin{array}{l}\text { 2. Did not meet market contract }(\mathrm{n}) \\
\text { requirements. } \\
\end{array}$ & $\begin{array}{l}10 \\
8.5 \% \\
\end{array}$ & $\begin{array}{l}4 \\
5.9 \% \\
\end{array}$ & $\begin{array}{l}14 \\
7.5 \% \\
\end{array}$ \\
\hline $\begin{array}{l}\text { 3. Market contract requirements (n) } \\
\text { slightly met. }\end{array}$ & $\begin{array}{l}35 \\
29.7 \% \\
\end{array}$ & $\begin{array}{l}30 \\
44.1 \% \\
\end{array}$ & $\begin{array}{l}65 \\
34.9 \% \\
\end{array}$ \\
\hline $\begin{array}{l}\text { 4. Market contract requirements }(\mathrm{n}) \\
\text { met. }\end{array}$ & $\begin{array}{l}1 \\
0.8 \%\end{array}$ & $\begin{array}{l}0 \\
0.0 \%\end{array}$ & $\begin{array}{l}1 \\
0.5 \%\end{array}$ \\
\hline $\begin{array}{l}\text { 5. Market contract requirements met }(\mathrm{n}) \\
\text { to a large extent. }\end{array}$ & $\begin{array}{l}1 \\
0.8 \%\end{array}$ & $\begin{array}{l}0 \\
0.0 \%\end{array}$ & $\begin{array}{l}1 \\
0.5 \%\end{array}$ \\
\hline $\begin{array}{ll}\text { 6. Market requirements totally met. } & (\mathrm{n}) \\
(\%)\end{array}$ & $\begin{array}{l}2 \\
1.7 \% \\
\end{array}$ & $\begin{array}{l}2 \\
2.9 \% \\
\end{array}$ & $\begin{array}{l}4 \\
2.2 \% \\
\end{array}$ \\
\hline $\begin{array}{l}(\mathrm{N}) \\
(\%)\end{array}$ & $\begin{array}{l}118 \\
100.0 \%\end{array}$ & $\begin{array}{l}68 \\
100.0 \%\end{array}$ & \begin{tabular}{|l|}
186 \\
$100.0 \%$ \\
\end{tabular} \\
\hline
\end{tabular}

$$
x^{2}=5.465 ; \mathrm{p}=0.353
$$

\subsection{Market assessment in terms of price as perceived by project participants and extension officers}

Financial awareness to farmers is essential to make sure that they make a proper assessment of all resources that they manage. Furthermore, farmers must be aware of financial loss (Lombard et. al., 1995:65-77). They must also be able to budget independently and be willing to interpret financial records so that they can make informed decisions. The perception of both respondent categories regarding the market price was assessed using a scale between very bad to very good. According to the majority of project participants (40\%) and extension 
S. Afr. J. Agric. Ext.

Vol. 45, No. 2, 2017: $38-48$

Matiwane \&

DOI: http://dx.doi.org/10.17159/2413-3221/2017/v45n2a432

Terblanché

(Copyright)

officers $(36 \%)$, the market price was average and only $3 \%$ of project participants and $1 \%$ of extension officers reported that the market was very good. A total of $29 \%$ of both respondent categories indicated that the price was good. Furthermore, $20 \%$ of project participants and $21 \%$ of extension officers reported that the market price was very bad. The Pearson ChiSquare $\left(x^{2}=3.823 ; \mathrm{p}=0.442\right)$ again indicated that there is no statistically significant difference at the 5\% significant level between the two respondent categories with regards to the market price. The majority $(70 \%)$ of both respondent categories indicated that the price received was average and even above average. This finding suggests that extension officers should assist farmers to a level where they get a good price for their produce.

\subsection{Market assessment in terms of the quantity it can absorb according to project participants and extension officers}

It is necessary for extension services to ascertain or make an assessment of the market in terms of the quantity of produce it can absorb as a form of assistance to the farmer, so that one knows what will happen if the farmer increases the rate of production. According to Burke (2003:2-4, 48-59), this will also determine how it will affect market share, through assessing competitors in the market. The majority of project participants (39\%) and extension officers $(36 \%)$ indicated that market assessment in terms of the quantity it can absorb is average. Only $8 \%$ of project participants and $7 \%$ of extension officers indicated a very good absorption of produce by the market. A total of only $23 \%$ of both respondent categories indicated a bad to very bad perception on the quantity the market can absorb. The Pearson Chi-Square $\left(x^{2}=0.827 ; \mathrm{p}=0.931\right)$ indicated that there is no statistically significant difference between the two respondent categories with regards to the market status. A small percentage ( $8 \%$ of project participants and $7 \%$ of extension officers) of good market absorption means that farmers must be careful when they plan quantities of produce for their market. Extension officers should assess the market situation and inform the farmer before a farmer can start to use his financial resources.

\subsection{Transportation of produce}

4.7.1 Transportation of produce to the market as perceived by project participants and extension officers

When establishing a project, the effect of location on the project must be considered (Burke, 2003), and the logistic requirements during the project and subsequent operation be met through existing roads and ports. 'How do participants or farmers get their produce to the market', was one of the questions raised during the survey. The highest total percentage according to both respondent categories (Table 4) was on hired transport (35\%), followed by buyers at the gate $(31 \%)$, other means of transport (18\%), and use of own transport $(16 \%)$. The Chi-Square test reveals an indication of an association $\left(x^{2}=7.737 ; \mathrm{p}=0.051\right)$ whereby project participation (38\%) makes use of hired transport and 31\% of extension officers indicated the use of hired transport as important. If the majority of farmers use hired transport, it means the income of the majority will be affected as illustrated in Table 5. Extension services should intervene by suggesting short term measures to encouraging them to sell at a particular time for them to share transport costs. Farmers must be advised to make contributions towards purchasing their own transport to cater for all their immediate needs. 
S. Afr. J. Agric. Ext.

Vol. 45, No. 2, 2017: $38-48$

DOI: http://dx.doi.org/10.17159/2413-3221/2017/v45n2a432

Table 4: The means of transporting produce to the market as perceived by both respondent categories.

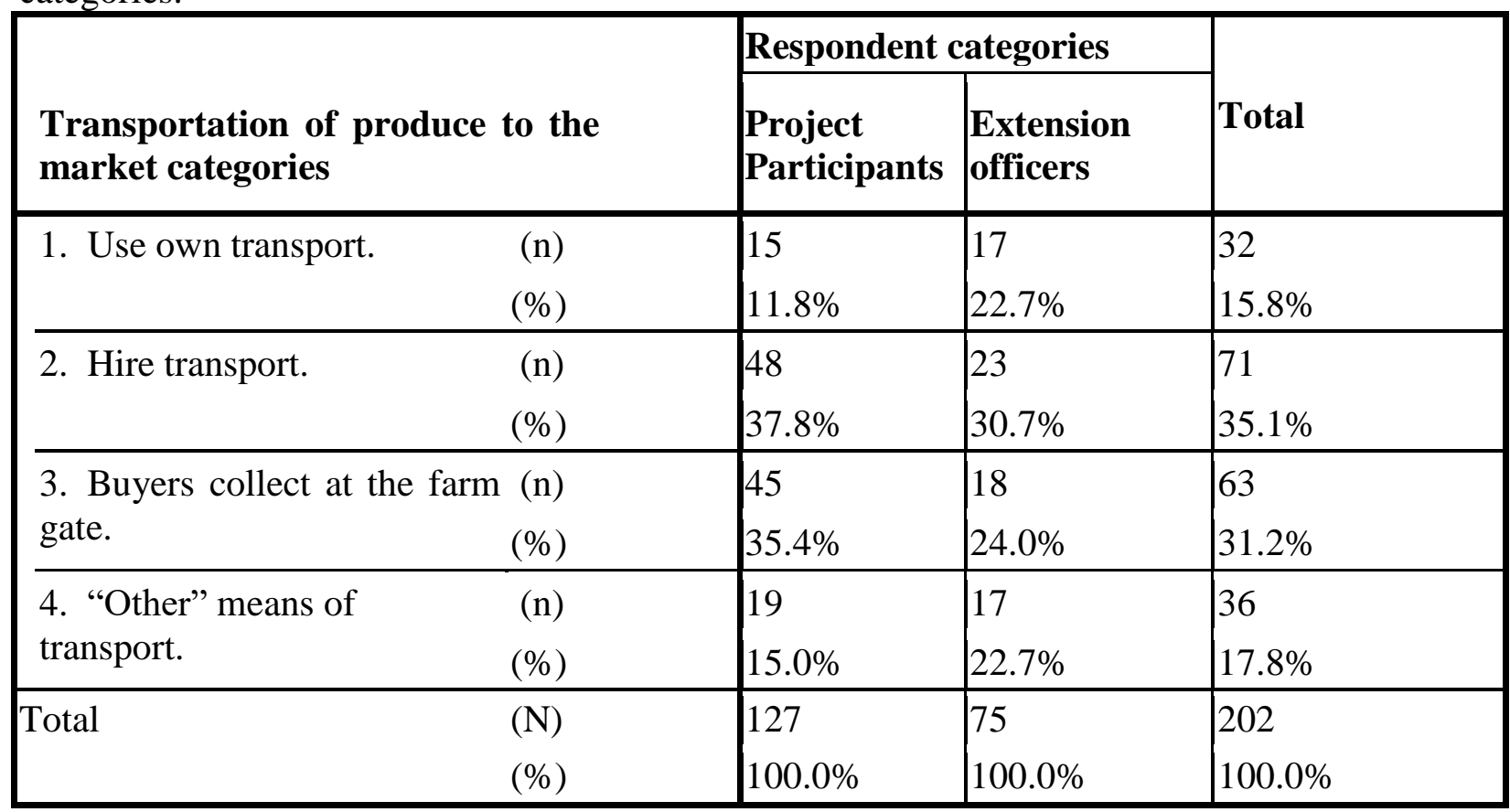

$x^{2}=7.737 ; \mathrm{p}=0.051$

\subsubsection{The percentage of the gross income on transport costs}

The mean transport cost according to project participants $(25.37 \%)$ and extension officers $(22.28 \%)$ are presented in Table 5. The T-test results $(\mathrm{t}=0.001 ; \mathrm{p}=0.334)$ indicates no statistically significant difference at the $5 \%$ significant level across the two respondent categories. The fact is that the cost of transport was between 22 and $25 \%$ of the gross income of the produce sold at the market.

Table 5: T-Test to compare the percentage of gross income on transport costs across type of respondent.

\begin{tabular}{|l|l|l|l|l|}
\hline $\begin{array}{l}\text { Type of } \\
\text { respondent }\end{array}$ & N & Mean & $\begin{array}{l}\text { Std. } \\
\text { Deviation }\end{array}$ & Std. Error Mean \\
\hline $\begin{array}{l}\text { Project } \\
\text { participants }\end{array}$ & 120 & $25.37 \%$ & $21.1541 \%$ & $1.9311 \%$ \\
\hline $\begin{array}{l}\text { Extension } \\
\text { officers }\end{array}$ & 72 & $22.28 \%$ & $21.7354 \%$ & $2.5615 \%$ \\
\hline
\end{tabular}

$$
\mathrm{t}=0.001 ; \mathrm{p}=0.334
$$

\subsection{Marketing place of produce as perceived by project participants and extension officers}

Once the project is established, regular assessment of the market supply and demand curve must be monitored so that the demand for the product now and forecast demand is known (Burke, 2003). Areas identified by the study where produce can be sold were: (a) farm gate; 
S. Afr. J. Agric. Ext.

Vol. 45, No. 2, 2017: $38-48$

DOI: http://dx.doi.org/10.17159/2413-3221/2017/v45n2a432
Matiwane \&

Terblanché

(Copyright)

(b) local community market; (c) auction sales; (d) open market; (e) pre-arranged market; (f) pension point; and ( $\mathrm{g}$ ) in town. The highest total percentage according to both respondent categories was at the local community market (33\%), followed by buyers at auction sales $(25 \%)$ and other means of marketing produce $(20 \%)$. The Chi - Square result $\left(x^{2}=13.128 ; \mathrm{p}\right.$ $=0.062$ ) reveals that there is no statistically significant difference at the $5 \%$ significant level between the report of participants and extension officers about where produce is sold. The importance of this finding is that before production, market must be known in terms of the distance, area, price, and arrangements such as contracts. Extension officers should advise farmers of such important variables that can ultimately affect their income.

\section{SUMMARY AND CONCLUSIONS}

The study compares the perception of the two groupings in relation to the most decisive variables in agricultural project marketing. The variables that were used to compare the perceptions of the two groupings were: (a) market availability, (b) performance status, (c) transport, and (d) meeting market requirement in terms of quality, quantity, contract, and price.

According to the National Development Plan for South Africa (National Planning Commission, 2012), there is an urgent need to invest substantially in providing innovative market linkages for small-scale farmers in communal and land reform areas. Specific attention should be given to linking farmers to "food away from home" markets, namely take-away outlets, school feeding schemes, and food services in hospitals. Project planners need to investigate the possibilities for opening access to the above mentioned "new" markets and link them with the project. No farming enterprise can start to generate produce without a market.

Any project should, amongst other reasons, be selected on the basis of whether the project will maintain market share, increase market share or consolidate market position. Market availability was assessed for the produce of the projects and the majority of both respondent categories $(54 \%)$ indicated that the market was reasonable, $26 \%$ indicated that the market was good, and only $16 \%$ indicated that there was no market.

\subsection{Conclusions}

Market stability with regards to the produce of the project has to be known and it is always important for farmers to produce commodities that have a good market. Government led market as stated in the National Development Plan (National Planning Commission, 2012) should also be explored, and where possible, a contract be entered into to formalise the market.

Serious problems to be addressed are:

a) Market quality requirements:

- $57 \%$ requirements only slightly met.

- $36 \%$ requirements not met.

b) Market contract requirements:

- $62 \%$ did not meet market contract requirements. 
S. Afr. J. Agric. Ext.

Vol. 45, No. 2, 2017: $38-48$

DOI: http://dx.doi.org/10.17159/2413-3221/2017/v45n2a432

- $35 \%$ slightly met contract requirements.

- $3 \%$ met contract requirements.

c) Market price $-70 \%$ of both respondent categories indicated that the price received was average and even above average.

d) Market transportation $-35 \%$ of both respondent categories indicated that transport was hired and $31 \%$ indicated that buyers collect produce at the farm gate.

e) Marketing of produce - the local community (33\%) and the auction (25\%) were the most important places for the project participants to market their products.

\subsection{Recommendations}

- The results of the quality of the produce needs serious attention and its quality should be aligned to market requirement;

- There is a positive market price, although efforts to improve it must be in place;

- The results of market contracts are alarming, serious attention is needed to have produce linked to formal market contracts to ensure a regular and fixed arrangement of sales of produce;

- The fact that the majority of project participants use hired transport, and few use own transportation is a cause for concern and should be addressed before it affects the sustainability of the project;

- It was further discovered that the majority (48\%) of both respondent categories indicated that the market remained unchanged, $37 \%$ improved as compared to $15 \%$ who indicated that the market decreased. Special attention need to be given to market improvement; and

- Markets need to be established or identified before approval of funds and farmers must indicate if they will be able to meet market needs in terms of quality, price, quantity and that they will have means to take their produce to the market.

\section{REFERENCES}

ALONGE, A. J. 2002. Traditional Institutions, Social Capital, and Multi-Institutional Partnerships for Agricultural Development: Implication for a New Extension Paradigm. $1-4$.

BURKE, R. 2003. Project Management, planning and control $4^{\text {th }}$ edition. Burke Publishing: 2-4, 48-59.

CHIPITA, S., CHRISTOPlOS, I. \& KATZ, E. 2008. Common framework on marketoriented agricultural advisory services. Neuchâtel group. Wageningen, Nederlands,1-37.

DÜVEL, G. H. 1995. An operational model for effective extension in South Africa. Proceedings of the $29^{\text {th }}$ conference, 27-29 June 1995. Eskom Training Centre, Midrand: 38-43.

KIRSTEN, J. \& MACHETE, C. 2005. Appraisal of Land Reform Projects in Northwest Province. Department of Agricultural Economics, Extension and Rural Development University of Pretoria: Pretoria. 
S. Afr. J. Agric. Ext.

Vol. 45, No. 2, 2017: $38-48$

DOI: http://dx.doi.org/10.17159/2413-3221/2017/v45n2a432

LOMBARD, P. P., HADEBE, V. S., LOUW, W. J. \& BOTHA, C. A. J. 1995. A pre-requisite for the successful implementation of Reconstruction and Development Programme in Agriculture. Proceedings of $29^{\text {th }}$ conference 27-29 June 1995.Escom Training Centre, Midrand.) AIAEE 2002 Proceedings of the 18th Annual Conference Durban, South Africa.

NATIONAL PLANNING COMMISSION. 2012. National Development Plan: Our future makes it work. Department of the Presidency, Republic of South Africa.

REGENESYS SCHOOL OF PUBLIC MANAGEMENT. 2002. Project Management Course. Developed and delivered by Regenesys School of Public Management. Midrand: 38-39. 